\title{
NOTES
}

\section{THE LEGAL HISTORY OF A CHANGING POPULATION: INTEGRATING MEXICAN AND U.S. LEGAL CUSTOMS IN THE AMERICAN SOUTHWEST}

\author{
Andrea Bottorff*
}

Over the next forty years, traditional racial and cultural demographics in the United States will change dramatically. According to the 2010 U.S. Census, White Americans ${ }^{1}$ make up about 75 percent of the total population and have experienced the slowest population growth of all racial groups over the last 10 years. ${ }^{2}$ By 2050 , "minority" groups-such as Hispanic, Black and Asian Americans-will outnumber White Americans and represent the majority of the population. ${ }^{3}$ These changes are happening sooner than previously predicted. ${ }^{4}$ Last year, the country reached a significant milestone when the number of "minority" babies surpassed

\footnotetext{
* J.D., University of Pittsburgh School of Law, 2012. Many thanks to my family for their love and support.

${ }^{1}$ For consistency, I have used the racial groups recognized by the U.S. Census Bureau, which "generally reflect a social definition of race recognized in this country and [are] not an attempt to define race biologically, anthropologically, or genetically." People and Households: Race, U.S. CEnSUS BuREAU, http://www.census.gov/population/race/ (last visited Mar. 10, 2012).

2 Lindsay Hixson, Bradford B. Hepler \& Myoung Ouk Kim, U.S. Census Bureau, The White POPULATION: 2010 CENSUS BRIEF 17 (Sept. 2011), available at http://www.census.gov/prod/ cen2010/ briefs/c2010br-05.pdf.

${ }^{3}$ Joel Kotkin, The Changing Demographics of America, SMithsOnIAn MAG., Aug. 2010, at 2, available at http://www.smithsonianmag.com/specialsections/40th-anniversary/The-Changing-Demographics-ofAmerica.html?c=y\&page $=1$.

${ }^{4}$ Sam Roberts, In a Generation, Minorities May Be the U.S. Majority, N.Y. TIMES, Aug. 13, 2008, available at $\mathrm{http}: / / \mathrm{www} . n y t i m e s . c o m / 2008 / 08 / 14 /$ washington/14census.html?pagewanted=all.
} 
the number of White babies, signaling greater population shifts expected in the coming years. ${ }^{5}$ These widespread demographic changes will have a deep legal and cultural impact on future generations. ${ }^{6}$

Immigration and increasing birth rates are causing these changes in population. ${ }^{7}$ In particular, the Hispanic population increased 43 percent between 2000 and 2010, representing more than half of the total population increase in the country. ${ }^{8}$ This increase coincides with ongoing immigration from Mexico and South America, which has ignited a nationwide debate about immigration reform. ${ }^{9}$ The Supreme Court in December 2011 agreed to hear the case Arizona v. United States to determine the legality of Arizona's controversial immigration law, ${ }^{10}$ which criminalized being an undocumented alien, required police officers to stop and question anyone who appeared to be an illegal immigrant, and allowed citizens to sue police officers suspected of inadequately upholding the law. ${ }^{11}$ The Arizona law faced much criticism, including from President Barack Obama ${ }^{12}$ and Mexican President Felipe Calderon, ${ }^{13}$ who called the law unfair and prejudicial. Conversely, supporters praised Arizona lawmakers for responding to pleas for tighter border control. ${ }^{14}$ Following Arizona's lead, Alabama, Georgia, Utah, South Carolina,

\footnotetext{
${ }^{5}$ Minorities Make Up Majority of U.S. Babies, CBS News, June 23, 2011, available at http:// www.cbsnews.com/2100-201_162-20073650.html?tag=contentMain;contentBody.

${ }^{6} I d$.

${ }^{7}$ Kotkin, supra note 3, at 1-2.

${ }^{8}$ Karen R. Humes, Nicholas A. Jones \& Roberto R. Ramirez, U.S. Census Bureau, Overview OF RACE AND HISPANIC ORIGIN: 2010 CENSUS BRIEF 3 (Mar. 2011), available at http:// www.census.gov/prod/cen2010/briefs/c2010br-02.pdf.

${ }^{9}$ Marc Lacey, Arizona Lawmakers Push for New Round of Immigration Restrictions, N.Y. TiMES, Feb. 23, 2011, available at http://www.nytimes.com/2011/02/24/us/24arizona.html?_r=1\&nl $=$ us\&emc=politicsemailema 4 .

${ }^{10} 567$ U.S. _ (2012); Jaclyn Belczyk, Supreme Court to hear Arizona immigration law challenge, JURIST (Dec. 12， 2011), http://jurist.org/paperchase/2011/12/supreme-court-to-hear-arizonaimmigration-law-challenge.php.

${ }^{11}$ Support Our Law Enforcement and Safe Neighborhoods Act, 2010 Ariz. Sess. Laws, ch. 113 (codified in scattered sections of ARIZ. REV. STAT. ANN. $\S 11,13,23,28,41)$.

${ }^{12}$ Steve Dotterer, Obama criticizes proposed Arizona illegal immigrant law, JURIST (Apr. 23, 2010), http://jurist.org/paperchase/2010/04/obama-criticizes-proposed-arizona.php.

${ }^{13}$ Megan McKee, Mexico President Criticizes Arizona Immigrant Law, JURIST (Apr. 23, 2010, 12:31 PM), http://jurist.law.pitt.edu/paperchase/2010/04/mexico-president-criticizes-arizona.php.

${ }^{14}$ William G. Ross, Arizona's Immigration Law: Constitutional, but . . , JURIST-ForUM (May 3, 2010), http://jurist.org/forum/2010/05/arizonasimmigrationlaw.php.
} 
Oklahoma, Mississippi and Indiana, all passed similar immigration legislation. ${ }^{15}$ Ultimately, the Supreme Court struck down most of the Arizona law as unconstitutional, ruling that the law infringed on the power of the federal government to make and enforce federal immigration laws. ${ }^{16}$ The controversy did not disappear, however, since the Court upheld part of the Arizona law that allowed state police to check the immigration status of individuals who have been stopped, detained, or arrested. ${ }^{17}$ As the debate continues, the Arizona law and other similar state laws reflect a growing interest in the future of immigration laws in the United States.

While immigration law continues to fuel arguments in the courts and in the political arena, it is only part of the broader issue of human migration and resulting population shifts. In fact, the immigration debate may have manifested, at least in part, as a backlash against the widespread demographic changes that the country is experiencing. As America's population changes, the country will likely feel pressure to show greater tolerance for differing traditions and cultures.

However, evidence of this type of integration of belief systems outside the Anglo-American canon is not often promoted in our national history. For example, many Americans perceive that both a physical border and a cultural border separate the U.S. and Mexico. From an historical perspective, the American Southwest, including Texas and California, has been a volatile land filled with power struggles between White and Hispanic Americans. Our history since the nineteenth-century Mexican War-after which the U.S. annexed much of the present-day Southwestcenters on these ongoing battles between the cultures. ${ }^{18}$

Our legal history also supports a stark separation of the cultures. Scholars have acknowledged a divide between the Mexican civil law tradition and the American common law tradition. ${ }^{19}$ American common law is based on the English tradition, while Mexican civil law, which was in place in the land that would later

\footnotetext{
${ }^{15}$ Clay Flaherty \& Meagan McElroy, US Immigration Law Feature: US Immigration and State Laws, JURIST, http://jurist.org/feature/featured/immigration/detail.php.

${ }^{16} 567$ U.S. (2012).

${ }^{17} I d$.

${ }^{18}$ See Ernesto Chavez, The U.S. War with MeXico: A Brief History with Documents 19-24 (2008).

${ }^{19}$ Dana V. Kaplan, Women of the West: The Evolution of Marital Property Laws in the Southwestern United States and Their Effect on Mexican-American Women, 26 WoMEN's RTS. L. REP. 139, 157 (2005).
} 
U N I V E R S I T Y O F P I T T S B U R G H L A W R E V I E W

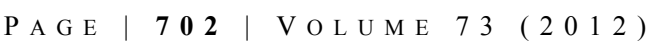

become the American Southwest during the nineteenth century, is based in Spanish law. ${ }^{20}$ Key differences between common law and civil law include common law's reliance on case law precedent, while civil law relies on codes, and common law's use of witness testimony in front of juries, while civil law uses written statements in court. ${ }^{21}$ American scholars have argued that, after gaining southwestern territory after the Mexican War, common law "was a device to Americanize the courts and assure "substantial security of life, liberty, and property.",22 Such reasoning implies that the Mexican system of law was untrustworthy and that the American system was superior.

However, this view is misleading and implies a broader separation of U.S. law and Mexican law than was actually in place; rather, American common law initially strove to integrate Mexican legal tradition into emerging case law after the end of the Mexican War. ${ }^{23}$ However, the law diverged drastically after the American conquest because of biased decisions that violated treaties, the U.S. Constitution, and common law precedent. $^{24}$ If attorneys and judges in the nineteenth-century American Southwest had respected this legal authority, the states would have had a greater integration of Mexican law from the early days of their U.S. territorial status and statehood. ${ }^{25}$ Still, despite evidence of U.S. and territory courts violating American legal tradition, some decisions preserved the Mexican laws that had been in place on the land for hundreds of years; some of these laws have even survived until the modern day. ${ }^{26}$

The arguments presented in this note have greater implications than simply providing an historical analysis. A closer study of U.S. legal history erases the myth that Mexican civil law and American common law were mutually exclusive and widened the divide between the two peoples. Rather, the intentions of early American jurists to incorporate previous civil laws into common law in the new states demonstrated Americans' willingness to integrate elements of Mexican

${ }^{20} I d$.

${ }^{21} I d$.

${ }^{22}$ Gordon Morris Bakken, The Development of LaW ON THE Rocky Mountain Frontier: Civil LAW AND SOCIETY, 1850-1912, at 24 (1983) (quoting Compiled Laws of New Mexico (1884)).

${ }^{23}$ Richard Griswold del Castillo, The Treaty of Guadalupe Hidalgo: A Legacy of Conflict 89-92 (1990).

${ }^{24}$ See infra Parts II, III.

${ }^{25}$ Id.

${ }^{26}$ See infra Part IV. 
culture into U.S. culture. ${ }^{27}$ Indeed, without the widespread corruption of the law during the nineteenth century, the American legal system would have supported fuller integration between Anglo-American and Mexican laws. Moreover, the survival of some of these laws into the present-day shows that the legal border allegedly separating Mexicans and Americans is not as well defined as some have argued. ${ }^{28}$ If the American legal system was inclined to integrate the laws of conquered Mexico, then perhaps it is also more inclined toward broader integration of differing viewpoints, particularly in areas experiencing rapidly changing demographics, such as the southern borderlands of the nation.

This note contains five parts. Part I describes the Mexican War and the history surrounding the legal landscape of the newly annexed American Southwest. Part II examines legal disputes surrounding Mexican land grants, including states' attempts to strip Mexicans or former Mexican citizens of their federally protected land titles, both in violation of the Treaty of Guadalupe Hidalgo and the U.S. Constitution. Part III focuses on water rights in California, Arizona, and New Mexico after the war and presents evidence of American courts misconstruing Mexican legal history to violate the terms of the treaty and distort water law precedent under the common law. Part IV describes the remnants of the old Mexican civil law that survived under the American common law. Finally, Part V concludes by suggesting that the legal authority at the close of the Mexican War called for integration of American and Mexican legal traditions, but was thwarted by greed, fraud and misrepresentation of legal history. In light of the country's rapidly changing demographics, jurists and politicians should be aware of this distinctly American legal history and consider the traditional role of integration in shaping not only laws and public policy, but also our national conscience.

\section{The MeXicAn WaR, 1846-1848}

In the mid-nineteenth century, Americans were passionate about manifest destiny, "the belief that Americans had a God-given right, based on racial superiority, to expand to the Pacific Ocean." ${ }^{29}$ This belief encouraged the

\footnotetext{
${ }^{27}$ See, e.g., Treaty of Peace, Friendship, Limits and Settlement between the United States of America and the Mexican Republic, U.S.-Mex., Feb. 2, 1848, 9 Stat. 922 [hereinafter Treaty of Guadalupe Hidalgo].

${ }^{28}$ See infra Part IV.

${ }^{29}$ CHAVEZ, supra note 18 , at 2 .
} 
government to pursue land acquisitions in the western part of North America and may have sparked the desire to fight a war with Mexico to gain more territory. ${ }^{30}$

One year after Texas won its independence from Mexico in 1836, the U.S. recognized Texas' sovereignty, souring the relationship between the U.S. and Mexico, which aimed to reclaim Texas. ${ }^{31}$ Over the next few years, the U.S. and Mexico disagreed over which country would annex Texas. ${ }^{32}$ Eventually, U.S. President James K. Polk offered to buy California, New Mexico, and other western lands from Mexico, but Mexican officials refused to sell the land. ${ }^{33}$ Fighting broke out between the nations in 1846, and although many believed the war would be short, the battles continued for two years in what would become known as the Mexican War. ${ }^{34}$

Finally, in February 1848, both nations signed the Treaty of Guadalupe Hidalgo, which ended the war and gave Mexico's northern territories to the U.S. ${ }^{35}$ After the war, the U.S. gained territory in what is now California, Arizona, New Mexico, Nevada, Utah, Wyoming and Colorado. ${ }^{36}$ The treaty established that the U.S. would honor property rights that had been granted or protected under the previous Mexican law. ${ }^{37}$ Article VIII of the treaty allowed Mexicans living on the disputed land the choice of becoming American citizens or moving to Mexico with the proceeds from their real property. ${ }^{38}$ The treaty also expressly protected the property rights of the conquered people:

In the said territories, property of every kind, now belonging to Mexicans not established there, shall be inviolably respected. The present owners, the heirs of these, and all Mexicans who may hereafter acquire said property by contract,

\footnotetext{
${ }^{30} I d$. at $2-4$.

${ }^{31} I d$. at 10 .

${ }^{32}$ Id. at $11-14$.

${ }^{33}$ Id. at $13-14$.

${ }^{34}$ Id. at $19-24$.

${ }^{35}$ See id. at 25 .

${ }^{36}$ Douglas V. Meed, Essential Histories: The MeXiCAn WAR, 1846-1848, at 88 (2003).

${ }^{37}$ Treaty of Guadalupe Hidalgo, supra note 27, at art. VIII.

${ }^{38} I d$.
} 
shall enjoy with respect to it guaranties equally ample as if the same belonged to citizens of the United States. ${ }^{39}$

Essentially, the U.S. agreed to honor the property rights of Mexicans living in the borderlands, as though the Mexicans were American citizens. However, U.S. officials refused to include in the treaty Article X, which had stated:

All grants of land made by the Mexican Government or by the competent authorities, in territories previously appertaining to Mexico, and remaining for the future within the limits of the United States, shall be respected as valid, to the same extent that the same grants would be valid, if said territories had remained within the limits of Mexico .... ${ }^{40}$

If this section of the treaty had been ratified, the U.S. would have had to honor all Mexican land grants and would have been very clear that "Mexican civil law, not Anglo-American common law, governed the adjudication of land titles." Nevertheless, the treaty was intended to shape common law precedent regarding property disputes in the new territories and states by upholding the property rights of Mexican landowners. Initially, the territorial courts upheld the terms of the treaty and protected the property rights left over from Mexican rule. However, as time went on, the courts began to violate the treaty and introduced biased common law decisions that created divisions where there had been more legal integration. ${ }^{42}$

\section{MeXican Land Grant Disputes}

A key provision of the Treaty of Guadalupe Hidalgo was that the U.S. government would honor land titles and property rights, previously observed by the Mexican government, of individuals who decided to remain on the land after American annexation following the Mexican War. ${ }^{43}$ However, after the land became part of the U.S., economic interests soon appeared to outweigh the

\footnotetext{
${ }^{39} I d$.

${ }^{40} \mathrm{Id}$.

${ }^{41}$ Christopher David Ruiz Cameron, One Hundred Fifty Years of Solitude: Reflections on the End of the History Academy's Dominance of Scholarship on the Treaty of Guadalupe Hidalgo, in THE LEGACY OF the Mexican and Spanish-American Wars: Legal, Literary, AND Historical Perspectives 1, 3 (Gary D. Keller \& Cordelia Candelaria eds., 2000).

${ }^{42}$ GRISwOld DEL CASTILlo, supra note 23.

${ }^{43}$ Treaty of Guadalupe Hidalgo, supra note 27, at art. VIII.
} 
established precedent of following the treaty. ${ }^{44}$ In particular, new American communities began selling former municipal tracts of land to individuals, due partly to pressure from new pioneers "to privatize the communal aspects of the Hispanic land system" and partly to the desire to earn an easy profit. ${ }^{45}$ The appetite for land drove some courts to uphold such land sales even while being aware that the sale violated laws protected under the treaty. ${ }^{46}$ Two key examples of this deception are the violation of individual land grants issued under Mexican rule and the erosion of Mexican communal land rights.

\section{A. Individual Land Grants}

After the Mexican War, California courts violated individual land grants that had been issued by Mexico prior to annexation. The California Land Act required anyone "claiming lands in California by virtue of any right or title derived from the Spanish or Mexican government" to provide written and testimonial evidence of the land ownership to register the Mexican title with American officials and have the land grant confirmed. ${ }^{47}$ In effect, the state law "adopt[ed] a legal presumption that Mexican landowners did not hold clear title." 48 The system of title review was flawed and, contrary to the terms of the Treaty of Guadalupe Hidalgo that protected property rights, many California landowners had difficulty or were unable to confirm their Mexican land grants with the new American government. ${ }^{49}$ Many Californians who had been wealthy landowners under Mexican rule found themselves pushed off their land after the war. ${ }^{50}$

Some scholars see the California Land Act as a direct violation of the treaty. ${ }^{51}$ On the national scale, life was also difficult for those who owned Mexican land titles. Evidence of Mexican litigants in Supreme Court cases between 1854 and 1930 almost disappeared, even though over 70 percent of the land grant disputes

\footnotetext{
${ }^{44}$ Peter L. Reich, Dismantling the Pueblo: Hispanic Municipal Land Rights in California Since 1850, 45 AM. J. LegAL Hist. 353, 361 (2001) [hereinafter Reich, Dismantling].

${ }^{45} I d$. at 358 .

${ }^{46}$ See id. at 360 .

${ }^{47}$ California Land Act, ch. 41, 9 Stat. 631 (1851), reprinted in CHAVEZ, supra note 18, at 131.

${ }^{48}$ Guadalupe T. Luna, Chicana/Chicano Land Tenure in the Agrarian Domain: On the Edge of a “Naked Knife," 4 MiCH. J. RACE \& L. 39, 80 (1998).

${ }^{49}$ California Landowners Petition to the Honorable Senate and House of Representative of the United States of America (Feb. 11, 1859), reprinted in CHAVEZ, supra note 18, at 133-36.

${ }^{50} \mathrm{Id}$.

${ }^{51}$ Cameron, supra note 41, at 6.
} 
involved Mexicans or former Mexicans who stayed on their land after the war and struggled to have their land ownership protected under the treaty. ${ }^{52}$

These land grant disputes reflected the American courts' willingness to undo the protections laid in the Treaty of Guadalupe Hidalgo. However, the harm to the American legal ideals went beyond a treaty violation - the misrepresentation and mistreatment of Mexican land grant owners also violated the U.S. Constitution. ${ }^{53}$ In particular, the U.S. "failed to honor the Treaty of Guadalupe Hidalgo and violated American constitutional norms protecting against governmental instrusions [sic] on private property rights. ${ }^{, 54}$ The failure of the treaty to honor Mexican communal land rights and individual land titles - after pledging to protect such property rights-violated the Constitution. ${ }^{55}$

\section{B. Communal Land Rights}

Some jurists willfully ignored the Mexican legal texts because of a fundamental conflict of interest: A number of lawyers and judges in the American Southwest were economically invested in the result of land dispute cases. ${ }^{56}$ In New Mexico, a group called the Santa Fe Ring - comprised of lawyers and politicianswas involved in economic pursuits tied directly to ownership of Mexican land grants. ${ }^{57}$ This group of corrupt lawyers acted as land surveyors and took advantage of selling land belonging to Mexicans to the highest bidder, making themselves rich as they fueled the engine of mining, ranching, and railroad interests. ${ }^{58}$ The corruption was widespread throughout the state, with localized "rings" controlling courts outside the capital. ${ }^{59}$ The Santa Fe Ring and other similar groups disregarded the Treaty of Guadalupe Hidalgo's protection of the Mexican land grants, instead

${ }^{52} I d$. at 10 .

${ }^{53}$ Luna, supra note 48 , at 47.

${ }^{54} I d$.

${ }^{55}$ Under the U.S. Constitution, American treaties are the "supreme Law of the Land." U.S. CONST. art. VI, cl. 2.

${ }^{56}$ Reich, Dismantling, supra note 44, at 362.

${ }^{57}$ BAKKEN, supra note 22, at 24.

${ }^{58}$ See id.; see also Jason Strykowski, Santa Fe Ring: Ruler of the Territory, SANTA Fe NeW MEXICAN, June 5, 2010, http://www.santafenewmexican.com/localnews/Santa-Fe-Ring--Ruler-of-the-territory.

${ }^{59}$ Marc Simmons, Trail Dust: Santa Fe Ring Remains an Enigma, Santa Fe New MeXican, Nov. 2, 2007, http://www.santafenewmexican.com/Local\%20News/Santa_Fe_ring_remains_an_enigma. 


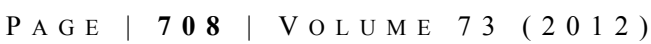

favoring twisted common law decisions that would protect their moneymaking schemes. $^{60}$

A similar distribution of Mexican land happened in California. ${ }^{61}$ Although California courts originally followed the terms of the Treaty and protected the land grants created under Mexican rule, ${ }^{62}$ the courts soon turned away from the Treaty and started creating a false precedent concerning communal land established under Mexican rule. For example, under Mexican law, certain lands were considered communal lands and were shared among residents, much like shared water sources in the desert. ${ }^{63}$ In 1853, Cohas v. Raisin overruled an earlier case upholding Mexican property rights by claiming incorrectly ${ }^{64}$ that old Mexican law gave municipalities the authority to grant land. ${ }^{65}$ The court moved further away from communal Mexican land-use laws and instead gave municipalities more power to dispose of public land, again by using false descriptions of Mexican laws. ${ }^{66}$ Cities' land rights gained strength at the expense of communal public land rights established under Mexican rule, even into the 20th century. ${ }^{67}$ Conveniently, the courts' use of inaccurate Mexican and Spanish law to support municipal land rights slowly morphed from incorrect historical references to cursory mentions, and eventually disappeared from the legal discussion. ${ }^{68}$ The courts' overt inconsistencies in land-use decisions shows the legal community's willingness to twist Mexican legal history to fashion a new precedent that would eventually undo the protections laid out in the Treaty of Guadalupe Hidalgo.

${ }^{60}$ BAKKEN, supra note 22 , at 24.

${ }^{61}$ Reich, Dismantling, supra note 44, at 363.

${ }^{62}$ See Woodworth v. Fulton, 1 Cal. 295 (1850) (holding that municipalities have no power to take or grant land under American or Mexican law); Ladd v. Stevensen \& Parker, 1 Cal. 18 (1850) (citing Mexican law in upholding the land rights of an individual who had been physically evicted from his land by the local municipal magistrate).

${ }^{63}$ See Peter L. Reich, Mission Revival Jurisprudence: State Courts and Hispanic Water Law Since 1850, 69 WASH. L. REV. 869 (1994) [hereinafter Reich, Mission].

${ }^{64}$ Reich, Dismantling, supra note 44, at 364.

${ }^{65}$ Cohas v. Raisin, 3 Cal. 443 (1853).

${ }^{66}$ Reich, Dismantling, supra note 44, at 364.

${ }^{67}$ See DeYoung v. City of San Diego, 194 Cal. Rptr. 722 (1983) (upholding San Diego's lease of public lands); Dunlop v. O'Donnell, 6 Cal. App. 2d 1 (1935) (allowing an underground tunnel to be built and used for private purposes underneath municipal land); City of Monterey v. Jacks, 73 P. 436 (1903) (supporting the right of the city of Monterey to sell its public land).

${ }^{68}$ Reich, Dismantling, supra note 44, at 369. 


\section{WATER Rights IN THE NEW SOUTHWEST}

U.S. courts knowingly and intentionally distorted Mexican historical legal doctrine in order to fabricate a common law precedent that allowed for more land purchases among Anglo-Americans at the expense of the Mexicans living in the new southwestern states. ${ }^{69}$ One example of this type of behavior involved pueblo water rights..$^{70}$ Pueblo means "civil municipality," and was used by the Spanish and Mexicans as a way of organizing towns around a "central plaza," with municipal governments that often included "an ayuntamiento or cabildo (town council), alcalde (mayor), and alcaldes ordinarios (judges)." ${ }^{, 71}$ Under Mexican law, these towns did not have individual water rights, but instead shared communal water rights and ensured that the scarce resource was distributed as needed. ${ }^{72}$

However, U.S. courts had a different view of water rights. For example, the riparian water law supported in the eastern U.S. derived from English common law, where the right to use water was based on whether an individual owned the land attached to the water source. ${ }^{73}$ Riparian water law called for "reasonable use" of water by property owners - this requirement also dovetailed with the Mexican communal water laws, which allowed for sharing among residents to ensure that everyone had the water that they needed to farm and live. ${ }^{74}$ In Arizona, California, and New Mexico, the courts twisted Mexican legal history to reach conclusions that diverged from riparian and communal water rights. ${ }^{75}$

\section{A. California}

When California came under American control, the state courts ruled in favor of the Mexican communal water law in their early decisions. ${ }^{76}$ For example, in the

${ }^{69}$ Reich, Mission, supra note 63 , at 869.

${ }^{70} \mathrm{Id}$.

${ }^{71} I d$. at 883 .

${ }^{72} I d$.

${ }^{73}$ Reed D. Benson, A Few Ironies of Western Water Law, 6 Wyo. L. REV. 331, 332 n.3 (2006).

${ }^{74}$ Reich, Mission, supra note 63, at 887.

${ }^{75}$ For a discussion on the division of water rights doctrine between the eastern U.S. states and the emerging western U.S. states, see Benson, supra note 73. For example, eastern riparian water rights "recognize rights to use water based on ownership of land along a natural watercourse," but prior appropriation, as it developed in the western frontier states, "recognize[] water rights based on diversion of water from its natural course and application to a "beneficial use."

${ }^{76}$ Reich, Mission, supra note 63 , at 887. 
1879 case City of Los Angeles v. Baldwin, the court refused to allow the city authorities to claim unlimited water rights over portions of the Los Angeles River used by local farmers to support their fields. ${ }^{77}$ The city officials wanted to stop upstream farmers from changing the water's course for irrigation, claiming that the city had an exclusive right to the water. ${ }^{78}$ However, the court ruled in favor of the farmers, saying that the city did not have an absolute right over the river water and upholding the idea of riparian water rights that were consistent with state law in the eastern U.S. ${ }^{79}$

The court addressed historical precedent in its concurrence to the decision. ${ }^{80}$ In the lower court decision, the city had argued that it had an absolute right to the river water "from its first settlement, about the year 1770," when the land was under Spanish rule. ${ }^{81}$ On the other hand, the farmers argued that they had been land titleholders during Mexican rule, they had a riparian right to use the water on their land, they did not take more than their "fair" share of the water, and they had been doing so for many years without any trouble. ${ }^{82}$ The court held for the defendants, disregarded the city's spin on Mexican history and supported the precedent of shared water rights. ${ }^{83}$

A couple of years later, the California Supreme Court again upheld the riparian water rights of upstream farmers along the Los Angeles River, although the tone of the court began to shift toward the city's point of view. ${ }^{84}$ In Feliz v. City of Los Angeles, farmers living in the same area as those in Baldwin filed suit against the city when Los Angeles officials forcibly prevented the farmers from diverting river water for their crops. ${ }^{85}$ As in Baldwin, the city officials argued that Los Angeles had an absolute right to the river water dating back to the Mexican

${ }^{77}$ City of Los Angeles v. Baldwin, 53 Cal. 469, 469 (1879).

${ }^{78} I d$.

${ }^{79}$ Id. at 470 .

${ }^{80} I d$. (Rhodes, J., concurring).

${ }^{81} I d$.

${ }^{82}$ Id. at 471.

${ }^{83} \mathrm{Id}$. at 469.

${ }^{84}$ Feliz v. City of Los Angeles, 58 Cal. 73 (1881); see also Elms v. City of Los Angeles, 58 Cal. 80 (1881) (upholding the riparian rights of upstream farmers over the alleged absolute pueblo water right of the city of Los Angeles in a companion case to Feliz).

${ }^{85}$ Feliz, 53 Cal. at 78. 
and Spanish times, but unlike Baldwin, the court agreed with the city's historical right to control the river water:

[T]he Pueblo of Los Angeles was established by the Mexican Government, as early as the year 1781, just one century ago, and ... during the occupation and control of said pueblo by the Mexican Government, the "municipal authorities exercised control of and claimed the exclusive right to use the waters of the Los Angeles River and all thereof, which right was duly recognized, acknowledged, and allowed by the owners of the land at the source and bordering on said river, including the grantors of the plaintiffs," and ... down to the period of two or three years last past, the municipal authorities have continued to exercise the same control and have claimed the same rights with respect to the waters of said river as was previously done by the pueblo. ${ }^{86}$

Although the court ultimately held for the city defendants, the decision emphasized that the city's exclusive pueblo water rights did not override the farmers' riparian right to use reasonable amounts of water. ${ }^{87}$ In a sense, Feliz was an in-between decision that set the stage for the city's later victory of absolute water rights, ${ }^{88}$ but still protected the communal water precedent set under Mexican rule, as well as the riparian law present in the eastern states. ${ }^{89}$

These California Supreme Court decisions were not only in line with the terms of the Treaty of Guadalupe Hidalgo, ${ }^{90}$ but also mirrored the alreadyestablished water law precedent in the eastern part of the country. ${ }^{91}$ The comparisons to established precedent go even further: scholars agree that Native Americans in the southwestern states used communal water rights before European colonization. ${ }^{92}$ However, the California courts would eventually distort this rich history and publish decisions that would contradict the established precedent under the common law and violate the treaty.

${ }^{86} I d$. (emphasis added).

${ }^{87}$ Id. at $79-80$.

${ }^{88}$ Lux v. Haggin, 10 P. 674 (Cal. 1886).

${ }^{89}$ Benson, supra note 73 , at 332-33.

${ }^{90}$ See Treaty of Guadalupe Hidalgo, supra note 27, at art. VIII.

${ }^{91}$ Reich, Mission, supra note 63 , at 887.

${ }^{92}$ Id. See also DANiel Tyler, The Mythical Pueblo Rights Doctrine: Water AdMinistration IN Hispanic New Mexico 13, 44 (1990). 
In a case factually similar to Baldwin and Feliz, the city of Los Angeles argued that the town had an exclusive right to the flowing river water and was thus allowed to divert as much as desired, regardless of reasonability. ${ }^{93}$ In Vernon Irrigation Co. v. City of Los Angeles, the California Supreme Court used alleged Mexican law as a basis for granting individual rights to the town, citing to the custom's ancient origin and connection to "medieval Spain." ${ }^{94}$ Despite prior case law holding the opposite, "the state's highest court had held that Los Angeles had an absolute and exclusive pueblo water right, ostensibly based on Hispanic law." ${ }^{, 5}$ However, this ruling was in direct contradiction with actual testimony and documents from Mexican law, which clearly supported communal water rights. ${ }^{96}$ The court had to intentionally ignore all of the historical evidence presented, including in the previous cases in which the court supported communal rights, in order to reach its decision. ${ }^{97}$ The court distorted the historical Mexican law to justify its failure to follow precedent, as well as to "justify urban water monopolization." 98

The shift in water law resulted from the court's reliance on distorted history and its erroneous claim that the municipal water monopoly was actually in the spirit of the old Mexican law. Instead, the California court violated both U.S. common law precedent of riparian water rights, as well as the terms of the Treaty, protecting the Mexican land titles owned at the time of annexation. The distorted view of water rights continued into the twentieth century and gained strength over time. ${ }^{99}$ Although more recent cases have shown disapproval of this water rights doctrine, the city's absolute right to water has not been overruled. ${ }^{100}$

${ }^{93}$ Vernon Irrigation Co. v. City of Los Angeles, 39 P. 762 (Cal. 1895).

${ }^{94}$ Reich, Mission, supra note 63, at 892.

${ }^{95}$ Id. at 893.

${ }^{96} I d$. at 894.

${ }^{97} \mathrm{Id}$.

${ }^{98} I d$. at 906.

${ }^{99}$ See City of Los Angeles v. City of San Fernando, 537 P.2d 1250, 1277 (Cal. 1975) (holding that Los Angeles had a pueblo water right and that the previous cases supporting the water right were not based on such incorrect history as to warrant an overruling); City of Los Angeles v. City of Glendale, 142 P.2d 289, 293 (Cal. 1943) (including water collected from floods within the pueblo water rights); City of San Diego v. Cuyamaca Water Co., 287 P. 475, 484-86 (Cal. 1930) (supporting the exclusive pueblo water rights of San Diego, despite opposing evidence of Mexican history); City of Los Angeles v. Hunter, 105 P. 755, 757 (Cal. 1909) (including underground basin water in Los Angeles' pueblo water right); City of Los Angeles v. Los Angeles Farming \& Milling Co., 93 P. 869, 872 (Cal. 1908) (holding that Los Angeles' water rights were appurtenant to its land rights, an historical rule based in Mexican law); Los 


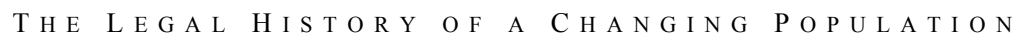

\begin{tabular}{l|ll}
$P$ A G E & 713
\end{tabular}

\section{B. Arizona}

When the United States gained control of the land that would become Arizona, the Mexican water law that had been in place for many years barred individual ownership of water and instead allowed water to be shared during droughts or other times of need. ${ }^{101}$ Scholars have traced these types of law to "medieval Spain" and even to areas in "the contemporary [American] Southwest." "102 However, evidence shows that Arizona's common law courts "knowingly misrepresented [Mexican] historical authority to justify exclusive water use" in the state. ${ }^{103}$

As in California, American courts in Arizona originally upheld the established Mexican law already in place, including the water laws. ${ }^{104}$ Both the Treaty of Guadalupe Hidalgo and the Kearny Code, a legal document created by American military leaders in the Southwest after the Mexican War, authorized this recognition of the Mexican laws by the American courts. ${ }^{105}$ Indeed, in Dalton v. Rentaria, the Arizona Supreme Court ruled in favor of downstream farmers who challenged their upstream neighbor's right to cut off the water supply for his own uses. ${ }^{106}$ The downstream farmers gave testimony that for at least forty years, including while under Mexican rule, the water had been shared communally. ${ }^{107}$ The upstream farmer argued that the ownership of the water source derived from "immemorial sources," presumably based in ancient history. ${ }^{108}$ Although the trial court had ruled in favor of the upstream farmer, the Arizona Supreme Court

\footnotetext{
Angeles v. Pomeroy, 57 P. 585, 600 (Cal. 1899) (extending pueblo water rights beyond the needs of the original pueblo of Los Angeles, allowing for future increases in city size and population).

${ }^{100}$ See, e.g., City of Barstow v. Mojave Water Agency, 5 P.3d 853, 860 n.7 (Cal. 2000) ("The state does not have the right to possess and use the water to the exclusion of others and has only such riparian, overlying, or appropriative rights as it may obtain by law; its interest is therefore not an ownership interest, but rather a nonproprietary, regulatory one.").

${ }^{101}$ Peter L. Reich, The "Hispanic" Roots of Prior Appropriation in Arizona, 27 ARIZ. ST. L.J. 650 (1995) [hereinafter Reich, "Hispanic" Roots].

${ }^{102} I d$. at 651 .

${ }^{103} I d$.

${ }^{104}$ Id. at 653.

${ }^{105} \mathrm{Id}$.

${ }^{106}$ Dalton v. Rentaria, 15 P. 37 (Ariz. 1887).

${ }^{107}$ Reich, "Hispanic" Roots, supra note 101, at 654.

${ }^{108} \mathrm{Id}$.
} 
reversed, in favor of the communal water rights of the downstream farmers. ${ }^{109}$ However, the court's interpretation of water law changed dramatically a year later in $1888 .^{110}$

In a departure from precedent and from the Treaty of Guadalupe Hidalgo's promise to uphold Mexican property rights, the Arizona Supreme Court ruled in Clough v. Wing ${ }^{111}$ that a different form of water rights called "prior appropriation," not riparian rights, "began in prehistoric Arizona with Native American canals and continued through the Spanish and Mexican periods."112 Even though the parties in the case-landowners in disagreement about the use of a local creek-did not cite history in their arguments, the Arizona court in the opinion used an outright distortion of history to justify the new prior appropriation doctrine of water law, in contrast to riparian doctrine. ${ }^{113}$ For example, the court appears to have misquoted Roman law as the basis for Spanish law that was brought to the former Mexican territory and supposedly mirrored Native American customs. ${ }^{114}$

However, the court did not actually present any evidence of old laws or customs present on the land, ${ }^{115}$ as the previous Dalton case had with the testimony from local landowners. Oddly, since the parties to the case had not raised history in their arguments, the court did not need to address the issue at all. ${ }^{116}$ Overall, the Clough decision not only violated the terms of the treaty by failing to uphold the farmers' water rights, but it also disregarded common law precedent protecting communal water rights.

After Clough, Arizona courts continued to perpetuate a mistaken belief in the Spanish or Mexican origins of prior appropriation in numerous court decisions throughout the rest of the nineteenth century and into the twentieth century. ${ }^{117}$ Not

${ }^{109} I d$. at 655 .

${ }^{110} I d$. at 656.

${ }^{111}$ Clough v. Wing, 17 P. 453 (Ariz. 1888).

${ }^{112}$ Reich, "Hispanic" Roots, supra note 101, at 656.

${ }^{113} I d$. at 657 .

${ }^{114} I d$.

${ }^{115} I d$.

${ }^{116} I d$.

${ }^{117}$ See Boquillas Land \& Cattle Co. v. Curtis, 89 P. 504, 508 (Ariz. 1907) (tracing prior appropriation to "the time when the Spaniards first settled in the valley" and characterizing riparian water rights as unknown to the settlers on the land since the days of Mexican rule), aff'd, 213 U.S. 339 (1909); Slosser v. Salt River Valley Canal Co., 65 P. 332 (Ariz. 1901) (recognizing that water rights were tied to land 
until 1968, in England v. Ally Ong Hing, did the Arizona Court of Appeals admit that the state judiciary's view of Mexican water law traditions had been incorrect. ${ }^{118}$ Mentioning Clough, the court of appeals said that previous court decisions describing prior appropriation as an old Mexican law and Native American custom was "erroneous." appropriation had been its later entry into the state legislation, not Mexican precedent. ${ }^{120}$ The court's admission of the mistake showed that the court aimed to redefine the basis for water law precedent in the state. The England court aimed to protect the foundation of its water law precedent by disregarding the incorrect descriptions of Mexican law and relying on the entry of prior appropriation into the state legislation.

\section{New Mexico}

Like California and Arizona, New Mexico courts promoted the inaccurate Mexican legal tradition of pueblo water rights. ${ }^{121}$ Interestingly, a twentieth-century case even stated that the New Mexico Supreme Court "has long recognized ... [and] ... followed the Mexican law of water rights rather than the common law," where the "Mexican law" is prior appropriation granting exclusive water rights to cities. ${ }^{122}$ The misunderstood history of the Mexican water laws infiltrated the New Mexican courts, just as it had in the Californian and Arizonan courts.

However, unlike the other southwestern states, New Mexico has since moved away from absolute municipality water rights. ${ }^{123}$ In State ex rel. Martinez v. City of

possession under the historical Mexican and Spanish laws); Biggs v. Utah Irrigating Ditch Co., 64 P. 494, 499 (Ariz. 1891) (holding that "old Spanish and Mexican laws" support a consideration of prior use in adjudicating water disputes); Oury v. Goodwin, 26 P. 376, 383 (Ariz. 1891) (finding that the ability of a judge to grant prior appropriation water rights to a company using a canal that passed through private property dated back to "old Mexico").

${ }^{118}$ England v. Ally Ong Hing, 446 P.2d 480 (Ariz. Ct. App. 1968), vacated, 459 P.2d 498 (Ariz. 1969).

${ }^{119} I d$. at 483 .

${ }^{120} I d$. at $483-84$.

${ }^{121}$ State ex rel. Cmty. Ditches v. Tularosa Cmty. Ditch, 143 P. 207, 208 (N.M. 1914) (upholding pueblo water rights only for cities established by land grants during Mexican rule). See also Cartwright v. Pub. Serv. Co. of New Mexico, 343 P.2d 654 (N.M. 1958) (protecting a city's exclusive water rights for use within the municipality), aff'd, 362 P.2d 796 (N.M. 1961), overruled by State ex rel. Martinez v. City of Las Vegas, 89 P.3d 47 (N.M. 2004); New Mexico Prods. Co. v. New Mexico Power Co., 77 P.2d 634, 639 (N.M. 1937) (finding that Santa Fe lacked pueblo water rights because the city was not settled under a Mexican land grant).

${ }^{122}$ Cartwright, 343 P.2d at 665.

${ }^{123}$ State ex rel. Martinez v. City of Las Vegas, 89 P.3d 47 (N.M. 2004). 
U N I V E R S I T Y OF P I T T S B U R G H L A W R E V I E W

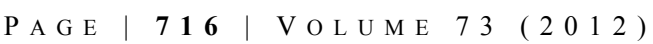

Las Vegas, the New Mexico Supreme Court overruled the previous Court of Appeals decision ${ }^{124}$ holding that pueblo water rights were based on a false history of Mexican law. Yet the court still abolished pueblo water rights from New Mexican law, citing legislative authority for prior appropriation rather than Mexican history. ${ }^{125}$ The prior appropriation doctrine had emerged from distorted Mexican legal traditions, yet it survived the New Mexico Supreme Court's renunciation of historical analysis because the doctrine had already been codified in state legislation.

\section{Modern Remnants OF MeXican CiVIL LAW IN SOUTHWESTERN STATES}

Southwestern courts misrepresented historical Mexican law in order to skew court decisions away from the terms of the Treaty of Guadalupe Hidalgo and to fabricate new precedents under the common law. While it may appear that state courts during the nineteenth and twentieth centuries turned away from the treaty's theme of integration, some modern state laws still reflect the blending of civil law with the common law. Examples of these vestiges of the Mexican civil law tradition include water law in Texas and marital property law in California and New Mexico.

\section{A. Texas Water Law}

Unlike its neighboring states of Arizona, California and New Mexico, the state of Texas never upheld pueblo water rights. ${ }^{126}$ In a twentieth-century case, the City of Laredo tried to exert a pueblo water right over other local riparian landowners, arguing that its exclusive municipal right to Rio Grande river water dated back to Spanish and Mexican rule. ${ }^{127}$ The Texas Court of Appeals examined the precedent in nearby jurisdictions, including California and New Mexico, to determine whether the old Mexican laws supported a pueblo water right. ${ }^{128}$

However, the court determined that the pueblo water rights upheld in its sister states were misconstrued. ${ }^{129}$ First, Texas criticized the California courts for basing

\footnotetext{
${ }^{124}$ State ex rel. Martinez v. City of Las Vegas, 880 P.2d 868, 874 (N.M. Ct. App. 1994), rev'd, 89 P.3d 47 (N.M. 2004).

${ }^{125}$ Martinez, 89 P.3d at 56-57.

${ }^{126}$ Reich, Mission, supra note 63, at 911.

${ }^{127}$ In re Contests of City of Laredo, 675 S.W.2d 257, 259 (Tex. Ct. App. 1984).

${ }^{128} I d$. at 268 .

${ }^{129} I d$.
} 
prior appropriation on a Spanish legal document, the Plan of Pitic, but omitting a key portion of the text that actually called for communal water rights. ${ }^{130}$ The Texas court had even harsher words for the New Mexican courts, which did not rely on "any specifically cited Spanish or Mexican law, regulation, or text" in its support of an alleged historical pueblo water right. ${ }^{131}$ Instead, the Texan appeals court accused New Mexico of adopting California's pueblo water right doctrine without first conducting an independent analysis. ${ }^{132}$ The court stated that precedent set in a nearby state is not necessarily binding in Texas and refused to uphold an exclusive water right for municipalities because such a law was not present in Mexican Texas. ${ }^{133}$ The Laredo case is thus distinguished from the California and New Mexico cases, showing that it was possible for courts to correctly interpret Mexican legal history and uphold the precedent as promised under the Treaty of Guadalupe Hidalgo.

\section{B. Marital Property}

In addition to Texas water rights, remnants of Mexican law still survive in some state marital property laws. ${ }^{134}$ In California, the only type of Mexican property right that survived in the new common law system was marital property. ${ }^{135}$ Under Mexican civil law, women owned all of their pre-marital property, as well as any property received during the marriage, and they could file lawsuits for themselves and testify against men in property disputes. ${ }^{136}$ This type of marital property law differed from the common law prevalent in the eastern U.S., where women lost their "legal identities" and did not possess such property rights. ${ }^{137}$

New Mexico also retained part of the Mexican civil law in its marital property law. ${ }^{138}$ Before marital property laws were officially passed in 1884 (codifying

\footnotetext{
${ }^{130} I d$. at 269.

${ }^{131} I d$. at 270.

${ }^{132} I d$.

${ }^{133} \mathrm{Id}$.

${ }^{134}$ Dana V. Kaplan, Women of the West: The Evolution of Marital Property Laws in the Southwestern United States and Their Effect on Mexican-American Women, 26 WOMEN's RTS. L. REP. 139, 153-57 (2005).

${ }^{135} I d$. at 153 .

${ }^{136} I d$. at 151 .

${ }^{137} I d$. at 148 .

${ }^{138} I d$. at 155 .
} 
U N I V E R S I T Y OF P I T T S B U R G H L A W R E V I E W

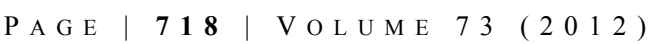

Mexican marital property laws in state statute), courts used a collection of temporary laws called the Kearny Code to direct the legal landscape in the new state. ${ }^{139}$ The Kearny Code called for all the Mexican laws to be upheld until more permanent legislation was enacted-this meant that women kept their legal identities and their portion of the marital property. ${ }^{140}$ Even when the common law tradition emerged in New Mexico law giving husbands administrative rights over communal marital property, women still owned their property. ${ }^{141}$ Adoption of the Mexican civil law marital property customs by California and New Mexico certainly benefitted women living in those states; although, some scholars have argued that the law was not the result of feminist legislators, but rather, was spurred by the fear of the "inevitable free-for-all" that would have resulted from uprooting the property law. ${ }^{142}$

\section{As American as ApPle Pie: InTegration in U.S. Legal AUTHORITY}

Although the differences between civil law and common law can be readily exposed, ${ }^{143}$ the beginnings of the American Southwest were cradled in legal documents, such as the Treaty of Guadalupe Hidalgo and the U.S. Constitution, which promoted at least some integration of the legal traditions. If the American courts had honored common law precedent and upheld their own constitutional values - respecting treaties and protecting citizens' property - then more of the civil law would have survived in the southwestern states under the Treaty of Guadalupe Hidalgo. Notwithstanding the deceptive changes in precedent that occurred with land grants and water rights, some vestiges of Mexican civil law survived the U.S. annexation of the southwestern states - evidence of integration in spite of legal fraud.

Without widespread corruption during the nineteenth century, the American legal system would have supported fuller integration between Anglo-American and Mexican laws. As the U.S. population continues to shift toward increasingly nonWhite demographics, this history is vital. The borderlands have been deeply rooted in legal authority promoting integration since their earliest days under U.S. law.

\footnotetext{
${ }^{139} I d$.

${ }^{140} I d$.

${ }^{141} I d$. at 156 .

${ }^{142} I d$. at 154

${ }^{143} I d$. at 157 .
} 


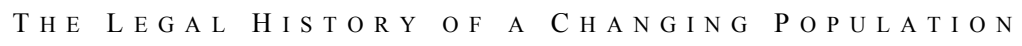

\begin{tabular}{l|l} 
P A G E & $\mathbf{7 1 9}$
\end{tabular}

Jurists and politicians studying this relevant yet overlooked chapter of American legal history will be better prepared to support the tradition of integration in future legal endeavors. 